\title{
Comparison of microbiological quality between illegal and inspected salami
}

\author{
Larissa Cristina Brassolatti1 (D) https://orcid.org/0000-0002-7336-4214 \\ Ludimila dos Santos Antônio² (D) https://orcid.org/0000-0001-8829-6237 \\ Camila Chioda de Almeida² (D) https://orcid.org/0000-0001-5454-5426 \\ Lucas José Luduverio Pizauro² (D) https://orcid.org/0000-0002-1071-8740 \\ Henrique Meiroz de Souza Almeida² (i) https://orcid.org/0000-0002-763 1-4271 \\ Gabriel Augusto Marques Rossi3,* (D) https://orcid.org/0000-0001-7967-7628 \\ 1. Centro Universitário Central Paulista - São Carlos (SP), Brazil. \\ 2. Universidade Estadual Paulista “Júlio de Mesquita Filho" - Faculdade de Ciências Agrárias e Veterinárias - Departamento de \\ Patologia, Reprodução e Saúde Única - Jaboticabal (SP), Brazil. \\ 3. Universidade Vila Velha - Departamento de Medicina Veterinária - Vila Velha (ES), Brazil. \\ *Corresponding author: gabriel.rossi@uvv.br
}

\begin{abstract}
The consumption of meat and meat products can pose consumers into risk due to the presence of biological hazards that can cause foodborne diseases. Thus, this study aimed to compare the microbiological quality of illegal and inspected salami sold in the state of São Paulo, Brazil. For this purpose, 80 salami samples (40 illegal and 40 inspected) were purchased and their microbiological quality was assessed according to the protocol established by the Brazilian Ministry of Health. All samples were considered as acceptable for consumption according to the Brazilian law. However, the samples of illegal salami were significantly higher contaminated with bacteria belonging to the genus Staphylococcus ( $p=0.002)$ and had a higher trend to be contaminated with total coliforms $(p=0.08)$ and thermotolerant ones $(p=0.07)$ compared to inspected salami. Salmonella spp. and coagulasepositive Staphylococcus were not detected. In conclusion, although all samples were considered as safe for consumption, illegal salami had a worse microbiological quality when compared to inspected ones.
\end{abstract}

Keywords: coliforms; meat; microbiology; Salmonella spp.; Staphylococcus spp.

Meat and meat products are excellent growth medium for bacteria and are commonly associated with foodborne disease outbreaks, such as those caused by Salmonella spp., Staphylococcus spp., and Escherichia coli (OMER et al., 2018). These microorganisms can cause a wide spectrum of clinical symptoms ranging from auto limiting intoxication (Staphylococcus aureus) to severe disease, characterized by bloody diarrhea and hemolytic uremic syndrome (HUS) (enterohemorrhagic E. coli [EHEC]) (FDA, 2012). These outbreaks result in high public health costs (MINOR et al., 2015) and are not completely described in Brazil, even though at least 12,503 outbreaks involving 236,403 humans occurred from 2000 to 2017 in this country (BRAZIL, 2018).

In Brazil, the hygienic and sanitary inspection of foods of animal origin has been mandatory for a long time (BRAZIL, 1950), to prevent foodborne illness. However, in Brazilian street markets, meat and dairy artisanal products are commonly produced and sold without proper inspection (BEHRENS et al., 2010) and their unsatisfactory microbiological conditions have been reported, i.e., for salamis (GOTTARDO et al., 2011; SALVATORI et al., 2003). Artisanal production of salamis usually involves natural fermentation without starter cultures, a wide range of spices and processes that results in nonstandardized products (SCHMITT, 2017), which can present improper physical-chemical characteristics, such as humidity or $\mathrm{pH}$ that allow bacterial survival and growth (GOTTARDO et al., 2011), which pose risks to public health. Therefore, this study aimed to assess if illegal (not inspected) and industrial salami sold in the state of São Paulo attended to the minimum microbiological parameters established in the current legislation as well as to compare their microbiological quality.

Received: May 12, 2020. Accepted: Oct 5, 2021

Associate Editor: Silvia Galleti

Peer Review History: Double-blind Peer Review. 
For this, a set of 80 salami samples ( 40 illegal and 40 industrial) was purchased at local supermarkets and street markets in the Mideastern region of the São Paulo state during 2019. The illegal products were those without a sanitary inspection service stamp on the packing and commercialized on street stalls. A set of five unities from the same lot (industrialized) or street stall (illegal) was bought, totalizing eight brands for each group. The parameters established by the Brazilian Health Regulatory Agency were used to assess samples microbiological quality, through counting coagulase-positive staphylococci, Salmonella spp. detection and assessing the most probable number (MPN) for thermotolerant coliforms (BRAZIL, 2001). All the microbiological analyses were performed according to DOWNES; ITO (2001) and BRAZIL (2003).

Briefly, initial dilution $\left(10^{-1}\right)$ was prepared by transferring $25 \pm 2 \mathrm{~g}$ of the sample to a sterile flask containing $225 \mathrm{~mL}$ of $0.1 \%$ peptone water (Difco). The $10^{-1}$ dilution was then processed inside sterile bags in a stomacher. The remaining dilutions $\left(10^{-2}, 10^{-3}, 10^{-4}, 10^{-5}\right.$ and $\left.10^{-6}\right)$ were prepared transferring $1 \mathrm{~mL}$ from the bags to tubes containing $9 \mathrm{~mL}$ of $0.1 \%$ peptone water. Staphylococci selective plating was done using $0.1 \mathrm{~mL}$ of these dilutions in Baird Parker agar (Difco) using a Drigalski spatula. Plates were incubated for $45-48 \mathrm{~h}$ under $35 \pm 1{ }^{\circ} \mathrm{C}$. Two to five suggestive black colonies were transferred into two tubes containing brain heart infusion broth (BHI) (Difco) and incubated for $24 \mathrm{~h}$ under $37^{\circ} \mathrm{C}$. One tube was used to perform the coagulase test using rabbit plasma (Newprov) (DOWNES; ITO, 2001) and the other tube was used for DNA extraction according to KURAMAE-IZIOKA (1997). A polymerase chain reaction (PCR), previously published by MARTINEAU et al., (2001), was performed to confirm Staphylococcus spp. genus.

Salmonella spp. detection was performed according to the following steps: (1) pre-enrichment using $1.0 \%$ peptone water at $37^{\circ} \mathrm{C}$ for $18-24 \mathrm{~h},(2)$ after time selective enrichment in Rappaport-Vassiliadis (Himedia) and selenite cystine (Himedia) broths with a $0.4 \%$ novobiocin solution, (3) selective plating on Agar MacConkey (Kasvi) and brilliant green agar (Kasvi) (BRAZIL, 2003; DOWNES; ITO, 2001). Since Salmonella spp. suggestive colonies were not detected, no additional steps were performed. For the MPN of total and thermotolerant coliforms, the DOWNES; ITO (2001) method was used using three sequential dilutions. The presumptive test for total coliforms used $1 \mathrm{~mL}$ of each dilution and Lauryl sulfate tryptose broth (LST) (Acumedia) and incubation occurred using $35^{\circ} \mathrm{C}$ during $24-48 \mathrm{~h}$. Positive tubes were confirmed transferring a loop to tubes containing brilliant green bile broth $(2 \%)$ (Acumedia) $\left(35^{\circ} \mathrm{C} / 24-48 \mathrm{~h}\right.$ ), while thermotolerant coliforms were verified using EC broth (Acumedia) $\left(45.5^{\circ} \mathrm{C} / 24-48 \mathrm{~h}\right.$ using water bath). Hoskins table was used to determine the MPN for these indicator microorganisms (DOWNES; ITO, 2001).

Initial statistical analyses were performed calculating means, variances and standard deviation for both groups for MPN of total and thermotolerant coliforms and Staphylococcus spp. counts. Kolmogorov-Smirnov (KS) test was used to assess data normality. Significant differences between sets of nonparametric data were assessed through Kruskal-Wallis test. All analyses were performed using $5 \%$ significance level $(\mathrm{p}<0.05)$ and, in addition, trends were considered when $0.1>\mathrm{p}>0.05$. All analyses were performed on Software R v.3.5.1 (R CORE TEAM, 2018).

A set of 35 illegal salamis presented Staphylococcus spp. contamination, while total and thermotolerant coliforms were detected in 11 and 7 samples, respectively. Staphylococcus spp. plate counts ranged from $1.5 \times 10^{3}$ to $9.0 \times 10^{7} \mathrm{CFU} \cdot \mathrm{g}^{-1}$, while the most probable number (MPN) for total and thermotolerant coliforms ranged from 3.6 to $43 \mathrm{MPN} \cdot \mathrm{g}^{-1}$ and 3 to $43 \mathrm{MPN} \cdot \mathrm{g}^{-1}$, respectively. Staphylococcus spp. was detected in 30 industrialized salamis $\left(1.3 \times 10^{3}\right.$ to $\left.5.2 \times 10^{6} \mathrm{CFU} \cdot \mathrm{g}^{-1}\right)$, and total and thermotolerant coliforms in five and two samples, respectively. Their counts ranged from 3.6 to $23 \mathrm{MPN} \cdot \mathrm{g}^{-1}$ for total coliforms and reached a maximum value of $3.6 \mathrm{MPN} \cdot \mathrm{g}^{-1}$ for thermotolerant coliforms. In addition, 164 suggestive colonies of Staphylococcus spp. were analyzed through PCR, which 161 (98.2\%) were genus confirmed. All Staphylococcus spp. colonies tested in this study were not coagulase producer and all samples could be considered safe for consumption by Brazilian law (BRAZIL, 2001).

A significant statistical difference ( $\mathrm{p}=0.002$ ) was detected between the mean counts of Staphylococcus spp. in illegal $\left(1 \times 10^{7} \mathrm{CFU} \cdot \mathrm{g}^{-1}\left[\mathrm{SD} \pm 2.4 \times 10^{7}\right]\right)$ and industrialized salamis $\left(3.5 \times 10^{5} \mathrm{CFU} \cdot \mathrm{g}^{-1}\left[\mathrm{SD} \pm 8.9 \times 10^{5}\right]\right)$. The first group had a trend for higher counts of total $\left(4.31 \mathrm{MPN} \cdot \mathrm{g}^{-1}[\mathrm{SD} \pm 10.57]\right)(\mathrm{p}=0.08)$ and thermotolerant coliforms $\left(3.07 \mathrm{MPN} \cdot \mathrm{g}^{-1}[\mathrm{SD} \pm 9.99]\right)(\mathrm{p}=0.07)$ compared to industrialized ones that showed a trend for lower means for total $\left(1.42 \mathrm{MPN} \cdot \mathrm{g}^{-1}\right.$ [SD \pm 5.0$\left.]\right)$ and thermotolerant coliforms (0.18 MPN.g-1 $[\mathrm{SD} \pm 0.79])$.

The higher counts detected in this study for Staphylococcus spp. and total and thermotolerant coliforms are probably related to differences in the physical-chemical characteristics among the salami groups. However, physical-chemical parameters were not evaluated in this study. Artisanal and illegal salami production occurs through natural meat fermentation and the use of a wide variety of manufacturing processes and spices. Thus, resulting in nonstandardized salamis, which can present a variation in $\mathrm{pH}$, humidity and water activity that can allow for bacterial survival and growth (GOTTARDO et al., 2011; SCHMITT, 2017), differing from industrialized meat products.

Staphylococcus spp. counts were high in all positive samples from both groups. The significantly higher count $(\mathrm{p}=000.2)$ mean in illegal salamis does not necessarily indicate a higher public health risk, but probably the higher 
contamination on artisanal salamis occurred due to unsatisfactory handling conditions during its production. Coagulase-positive staphylococci were not detected and the main species found on the salamis was Staphylococcus xylosus, a nonenterotoxigenic specie used as fermentation starter culture in meat products to extend shelf life and improve sensory characteristics (FIORENTINI, 2008). In addition, these starter cultures are also used to control meat products pathogens, such as Salmonella spp. (BRAGA et al., 2013), which were not detected in this study. However, the potential of coagulase-negative staphylococci in producing enterotoxins has been discussed (NASCIMENTO et al., 2020), and the antimicrobial resistant strains of staphylococci have been detected in starter cultures and had the capacity to transfer antimicrobial resistance-related gene during meat fermentation, contributing to risks for public health (LEROY et al., 2019; RESCH et al., 2008).

The trend of higher total and thermotolerant coliform detection in illegal salamis indicates worse hygienic and sanitary practices during manufacturing and/or handling. The presence of thermotolerant coliforms in meat and meat products may occur due to improper decontamination of equipment and utensils or the hands or contaminated ingredients (MATOS et al., 2012). OLIVEIRA et al. (2014) compared the microbiological quality of artisanal and industrialized salamis. These authors detected a better quality in industrialized salami and a set of samples of artisanal in disagreement with the humidity and protein levels parameters established in Brazil, highlighting the importance of hygienic and sanitary practices to avoid foodborne illness due to the consumption of illegal meat products.

In conclusion, all samples of illegal and industrial salamis attended to the microbiological parameters established in Brazil, however, a trend for a worse microbiological quality was detected in illegal samples. These findings highlight the importance of sanitary inspection of meat products to protect consumers' health and promote public health.

\section{AUTHORS' CONTRIBUTIONS}

Conceptualization: Brassolatti, L.C.; Rossi, G.A.M; Almeida, H.M.S. Data curation: Brassolatti, L.C.; Almeida, H.M.S. Formal analysis: Brassolatti, L.C.; Antonio, L.S.; Almeida, C.C.; Pizauro, L.J.L; Almeida, H.M.S. Funding acquisition: Brassolatti, L.C.; Rossi, G.A.M. Investigation: Antonio, L.S.; Rossi, G.A.M.; Almeida, C.C.; Pizauro, L.J.L. Methodology: Antonio, L.S.; Rossi, G.A.M.; Almeida, C.C.; Pizauro, L.J.L. Project administration: Rossi, G.A.M. Writing - original draft: Brassolatti, L.C.; Rossi, G.A.M; Antonio, L.S.; Almeida, C.C.; Pizauro, L.J.L; Almeida, H.M.S. Writing - review \& editing: Rossi, G.A.M; Almeida, H.M.S.

\section{AVAILABILITY OF DATA AND MATERIAL}

The datasets generated and/or analyzed during the current study are available from the corresponding author on reasonable request.

\section{FUNDING}

Fundação de Amparo à Pesquisa do Estado de São Paulo https://doi.org/10.13039/501100001807

Grant No. 2018/16844-7

\section{CONFLICTS OF INTEREST}

All authors declare that they have no conflict of interest.

ETHICAL APPROVAL

Not applicable.

\section{ACKNOWLEDGEMENTS}

Not applicable.

\section{REFERENCES}

DOWNES, F.P.; ITO, K. Compendium of methods for the microbiological examination of foods. Washington: APHA, 2001. 975p. 
BRAGA, H.F.; FERREIRA, I.M.; ROSSI, D.A.; BONAS, D.S. Biopreservação de salame tipo italiano por cultura starter. PUBVET, Londrina, v.7, n.14, p.1304-1450, 2013. https://doi.org/10.22256/pubvet.v7n14.1561

BRAZIL. Lei No 1.283, de 18 de dezembro de 1950. Dispõe sobre a inspeção industrial e sanitária dos produtos de origem animal. Brasília: Diário Oficial da União, 1950. Available from: http://www.planalto.gov.br/ccivil_03/leis/L1283.htm. Access on: 19 July 2018.

BRAZIL. Ministério da Saúde, Agência Nacional de Vigilância Sanitária. Resolução-RDC nº 12, de 2 de janeiro de 2001. Aprova o regulamento técnico sobre padrões microbiológicos para alimentos. Diário Oficial da União, 2001. Available from: https://bvsms.saude. gov.br/bvs/saudelegis/anvisa/2001/res0012_02_01_2001.html. Access on: 20 July 2018.

BRAZIL. Secretaria de Agricultura e Abastecimento, Coordenadoria de Defesa Agropecuária. Instrução normativa nº 62 de 26 de agosto de 2003. Oficializar os Métodos Analíticos Oficiais para Análises Microbiológicas para Controle de Produtos de Origem Animal e Água. Diário Oficial da União, 2003. Available from: https://www.defesa.agricultura.sp.gov.br/legislacoes/instrucao-normativa-sda62-de-26-08-2003,665.html. Access on: 20 July 2018.

BRAZIL. Ministério da Saúde, Secretaria de Vigilância em Saúde, Departamento de Vigilância das Doenças Transmissíveis, Coordenação Geral de Doenças Transmissíveis. Surtos de Doenças Transmitidas por Alimentos no Brasil. Brasília: Ministério da Saúde, 2018. Available from: http://portalarquivos2.saude.gov.br/images/pdf/2018/janeiro/17/Apresentacao-Surtos-DTA-2018.pdf. Access on: 20 July 2018.

FDA - Food and Drug Administration. Bad Bug Book, Foodborne Pathogenic Microorganisms and Natural Toxins. 2nd. ed. Silver Spring: FDA, 2012. Available from: https://www.fda.gov/media/83271/download. Access on: 19 July 2018.

FIORENTINI, Â.M. Caracterização e propriedades tecnológicas de staphylococcus xylosus isoladas de salames artesanais e aplicação como cultura iniciadora em salame tipo milano. 2008. Dissertation (Doctorate in Food Technology) - Universidade Federal de Santa Catarina, Florianópolis, 2008. Available from: https://repositorio.ufsc.br/xmlui/handle/123456789/91087. Access on: 19 Aug. 2019.

GOTTARDO, E.T.; VIANA, C.; BARCELLOS, V.C.; ZANETTE, C.M.; BERSOT, L.S. Embutidos cárneos fermentados artesanais como veículos de micro-organismos patogênicos de importância para a Saúde Pública. Boletim Centro de Pesquisa de Processamento de Alimentos, Curitiba, v.29, n.1, p.97-102, 2011. https://doi.org/10.5380/cep.v29i1.22761

KURAMAE-IZIOKA, E.E. A rapid, easy and high yield protocol for total genomic DNA isolation of Colletotrichum gloeosporioides and Fusarium oxysporum. Revista Unimar, Marília, v.19, n.3, p.683-689, 1997. Available from: http://periodicos.uem.br/ojs/index.php/ RevUNIMAR/article/view/4550. Access on: 16 Dec. 2019.

LEROY, S.; CHRISTEANS, S.; TALON, R. Tetracycline gene transfer in Staphylococcus xylosus in situ during sausage fermentation. Frontiers in Microbiology, Lausanne, v.10, p.392, 2019. https://doi.org/10.3389/fmicb.2019.00392

MARTINEAU, F.; PICARD, F.J; KE, D.; PARADIS, S.; ROY, P.H.; OUELLETTE, M.; BERGERON, M.G. Development of a PCR assay for identification of staphylococci at genus and species levels. Journal of Clinical Microbiology, Boston, v.36, n.7, p.2541-2547, 2001. https:// doi.org/10.1128/JCM.39.7.2541-2547.2001

MATOS, V.S.R.; GOMES, A.P.P.; SANTOS, V.A.; FREITAS, F.; SILVA, I.M.M. Perfil sanitário da carne bovina in natura comercializada em supermercados. Revista do Instituto Adolfo Lutz, São Paulo, v.71, n.1, p.187-192, 2012. Available from: https://docs.bvsalud.org/biblioref/ ses-sp/2012/ses-25882/ses-25882-3751.pdf. Access on: 2 Apr. 2021.

MINOR, T.; LASHER, A.; KLONTZ, K.; BROWN, B.; NARDINELLI, C.; ZORN, D. The per case and total annual costs of foodborne illness in the United States. Risk Analysis, Denver, v.35, n.6, p.1125-1139, 2015. https://doi.org/10.1111/risa.12316

NASCIMENTO, A.L.; SOUSA, R.S.; RODRIGUES, A.A.R.; MATTOS, E.C.; DAROS, V.S.M.G.; COL, R.D.; PINHEIRO, E.S.; NASSAR, A.F.C. Detection of virulence factors in coagulase-negative Staphylococcus spp. strains isolated from Emmental cheese. Arquivos do Instituto Biológico, São Paulo, v.87, p.e0812019, 2020. https://doi.org/10.1590/1808-1657000812019

OLIVEIRA, D.F.; BRAGHINI, F.; SILVEIRA JÚNIOR, J.F.S.; COELHO, A.R.; TONIAL, I.B. Condições higiênico-sanitárias e composição nutricional de salames artesanais e industrializados: Uma comparação. Arquivos de Ciências da Saúde da UNIPAR, Umuarama, v.18, n.3, p.151-156, 2014. https://doi.org/10.25110/arqsaude.v18i3.2014.5190 
OMER, M.K.; ÁLVAREZ-ORDOÑEZ, A.; PRIETRO, M.; SKJERVE, E.; ASEHUN, T.; ALVSEIKE, O.A. A Systematic Review of Bacterial Foodborne Outbreaks Related to Red Meat and Meat Products. Foodborne Pathogens \& Diseases, Knoxville, v.15, n.10, p.598-611, 2018. https://doi.org/10.1089/fpd.2017.2393

R CORE TEAM. A language and environment for statistical computing. R Foundation for Statistical Computing, Vienna, Austria, 2018. Available from: https://www.R-project.org/. Access on: 12 Dec. 2019

RESCH, M.; NAGEL, V.; HERTEL, C. Antibiotic resistance of coagulase-negative staphylococci associated with food and used in starter cultures. International Journal of Food Microbiology, v.127, n.1-2, p.99-104, 2008. https://doi.org/10.1016/j.ijfoodmicro.2008.06.013

SALVATORI, R.U.; BESSA, M.C.; CARDOSO, M.R.I. Qualidade sanitária de embutidos coletados no mercado público central de Porto Alegre-RS. Ciência Rural, Santa Maria, v.33, n.4, p.771-773, 2003. https://doi.org/10.1590/S0103-84782003000400031

SCHMITT, B. Avaliação sensorial do uso de diferentes culturas iniciadoras na produção de salame tipo italiano do Frigorífico Antônio Carlos. 2017. Undergraduate thesis (Bachelor Degree in Food Engineering) - Universidade Federal de Santa Catarina, Florianópolis, 2017. Available from: https://repositorio.ufsc.br/bitstream/handle/123456789/178186/TCC\%20Beatriz\%20Schmitt.pdf?sequence=1\&isAllowed=y. Access on: 16 Dec. 2019. 